\title{
Coarctation of Aorta
}

\section{Jayesh V Trivedi*}

Gujarat Adani Institute of Medical Sciences (GAIMS), G K General Hospital, India

Submission: January 12, 2018; Published: March 22, 2018

"Corresponding author: Jayesh V Trivedi, Gujarat Adani Institute of Medical Sciences (GAIMS), G K General Hospital, India, Email:drjvtrivedi@rediffmail.com

\section{Mini Review}

Coarctation of aorta occurs in 5 to $8 \%$ of patients with congenital heart diseases patient .It is one of the cause of secondary Hypertension in young patients. It may be isolated or may be accompanied by congenital cardiac diseases like Ventricular septal disease or Bicuspid Aortic valve. Sometimes it is associated with Left ventricular heart failure. It may be associated with Turner's syndrome.Coarctation of aorta is defined as consrticted aortic segment that comprises localised medial thickening with some infolding of medial and superimosed neonatal tissues. The Coarctation may be discrete or long segment of aora may be involved.

\section{a) Preductal Coarctation \\ b) Ductal Coarctation \\ c) Postductal Coarctation}

The classical coarctation of aorta is in thoracic aorta after the origin of left subclavian artery. Rarely it may be seen in lower thoracic aorta or abdominal aorta. Usually all coarctations are Diagnosis juxtaductal. Post stenotic dilatation of aorta is commonly seen and it occurs due to jet effect of the blood flow distal to the occlusion. As it is congenital disorder other associated disorders like Patenet Ductus Artereosus, Transposition of great vessels, Tricuspid atresia and Hypoplastic left ventricle syndrome is tobe rulled out [1-5].

\section{Signs and Symptoms}

Common in boys than girls. Girls with Turner syndrome are likely to have coarctation. Usaully children are asymptomatic but may present as Left ventricular failure. Intermittent claudication occur at a later age. Hypotension or absent pulsation in lowerlimb and hypertension in upperlimb is common. Infective endocrditis can take place. Mitral prolapse is associated with this. Differential cyanosis is also oneclinical presentation. Usally children are asymptomatic and in adults at about 40 years this is diagnosed. However some patients do get chest pain, cold feet, leg cramps with exercise, poor growth in lower half of body, epistaxis [6].

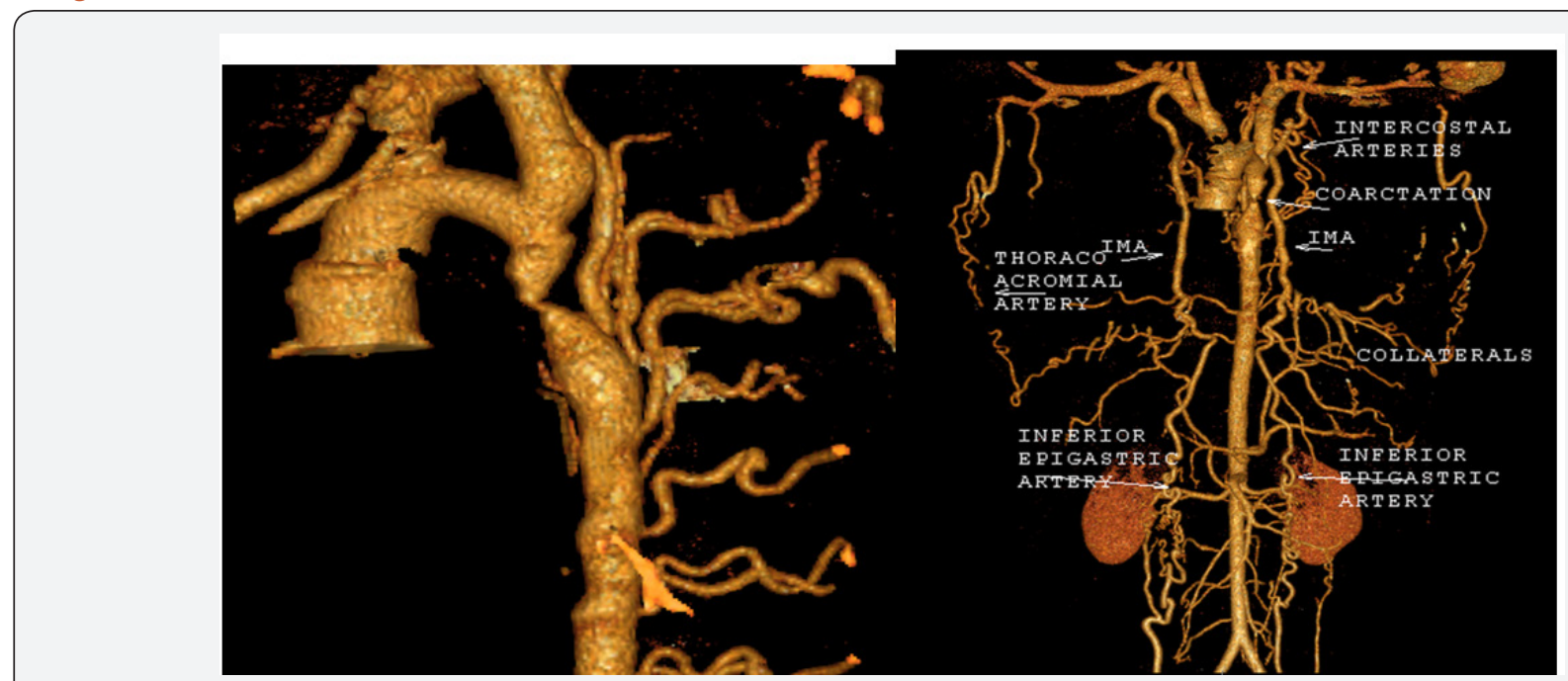

Figure 1: MRI picture of one of our patient. 
Pulse in the lower limb will be weaker than upper limb and radio femoral delay can be felt. On ausculation murmur will be audible on chest or back. Cardiac catheterisation and aortography helps in localising the extent of coarctation but they are invasive tests [7] (Figure 1).

Post stenotic dilatation will have inverted 3 appearance on chest x-ray. With prominent lower intercostal grooves on ribs due to dilated intercostal arteries. Echocardiography is helpful in children. Magnetic resonance angiogaphy is the most accurate test to diagnose Coarctation of aorta. Contrast MRI and Phase Contrast MRI are special investigation to diagnose the sevearity of the disease.

Rarely it is being diagnosed at the time of pregnancy in female while treating secondary pregnancy associated hypertension. Circle of willis abnormalities in the brain is also associated with Coarctation of Aorta. This results in to stroke in adults. This may be the cause of habitual abortion in females [8].

\section{Conclusion}

Fainting and chest pain in paediatric practice is being ignored but in such case suspicious of coarctation should be done. One

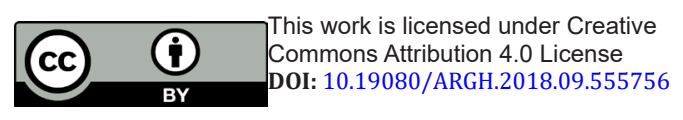

should always form a habbit of palpating pulse in all four limbs. Secondary hypertension should be investigated. Whenever congintal heart disease is diagnosed associated coarctation of aorta should be excluded. Patiets having coarctation of aorta should receive proper antibiotics for the prevention of infective endocarditis.

Early diagnosis will help in proper development of child and helps in preventing the complications.

\section{References}

1. Coarctation of the aorta - Mayo Clinic

2. www.mayoclinic.org/diseases-conditions/coarctation-of-theaorta/.../con-20031772

3. Coarctation of the Aorta (CoA) - American Heart Association

4. www.heart.org/.../Coarctation-of-the-Aorta-CoA_UCM_307022_ Article.jsp

5. Coarctation of the aorta: MedlinePlus Medical Encyclopedia

6. https://medlineplus.gov > Medical Encyclopedia

7. Co-arctation of the Aorta | Congenital Heart Defects UK - chd-uk.co.uk

8. www.chd-uk.co.uk/types-of-chd-and-operations/co-arctation-of-theaorta/

\section{Your next submission with JuniperPublishers will reach you the below assets}

- Quality Editorial service

- Swift Peer Review

- Reprints availability

- E-prints Service

- Manuscript Podcast for convenient understanding

- Global attainment for your research

- Manuscript accessibility in different formats

( Pdf, E-pub, Full Text, audio)

- Unceasing customer service

Track the below URL for one-step submission https://juniperpublishers.com/online-submission.php 